\title{
Naudan rasvoittumiseen vaikuttavat tekijät
}

\author{
Arto Huuskonen ${ }^{1)}$ ja Päivi Lamminen ${ }^{2)}$ \\ ${ }^{1)}$ Maa- ja elintarviketalouden tutkimuskeskus, Kotieläintuotannon tutkimus, Halolantie 31A, 71750 \\ Maaninka,arto.huuskonen@mtt.fi \\ ${ }^{2}$ Oulun seudun ammattikorkeakoulu, Luonnonvara-alan yksikkö, Metsäkouluntie, 90650 Oulu, \\ paivi.lamminen@oamk.fi
}

\section{Tiivistelmä}

Tämän kirjallisuusselvityksen tarkoituksena oli kartoittaa mahdollisuuksia vaikuttaa naudan ruhon rasvoittumiseen. Lihas- ja rasvakudoksen kasvu perustuu niissä olevien solujen koon suurenemiseen ja/tai niiden lukumäärän lisääntymiseen. Kudosten kasvuun ja valkuaisaineenvaihduntaan vaikuttavat lukuiset kasvutekijät ja hormonit. Kasvunopeudella on erityisesti vaikutusta lihanlaatuun, sillä nopeasti kasvaneet naudat voidaan teurastaa nuorempina, millä on myönteinen vaikutus lihan syöntilaatuun. Nopeaan kasvuun liittyy yleensä myös rasvoittuminen: nopeasti kasvaneet eläimet ovat yleensä rasvaisempia kuin hitaasti kasvaneet eläimet. Rasvan kertyminen ruhoon lisääntyy päiväkasvun nopeutuessa ja energian saannin lisääntyessä. Myös teuraspainon kasvu lisää yleensä ruhojen rasvaisuutta ja vähentää lihan sekä luun osuutta.

Sukupuolen vaikutus ruhon koostumukseen näkyy erilaisissa rasvoittumistaipumuksissa. Hiehot rasvoittuvat aikaisemmin kuin härät, jotka puolestaan rasvoittuvat aikaisemmin kuin sonnit. Eri nautarodut eroavat toisistaan rasvoittumispisteen (ts. missä painossa eläin alkaa rasvoittua) osalta. Aikuispainoltaan suurikokoiset rodut (esim. Charolais, Simmental ja Limousin) kasvavat nopeammin ja rasvoittuvat hitaammin kuin pienikokoiset rodut (Aberdeen angus, Hereford, Highland cattle).

Ruokinnan energiapitoisuuden pienentäminen vähentää yleensä ruhojen rasvoittumista, mutta hidastaa myös usein eläinten kasvua ja pidentää siten kasvatusaikaa. Jos halutaan vähentää ruhojen rasvoittumista dieetin energiapitoisuutta pienentämällä, joudutaankin yleensä hyväksymään hieman heikommat kasvutulokset. Valkuaislisän vaikutukset ruhon koostumukseen ovat yleensä olleet vähäisiä. Erilaisten karkearehujen ja väkirehujen käytöllä ei ole tutkimuksissa ollut vaikutusta ruhojen rasvoittumiseen, jos eläinten energian ja valkuaisen saanti ovat olleet samalla tasolla eri ruokintaryhmien välillä.

Lisääntyneen liikunnan on esitetty ehkäisevän nautojen rasvoittumista. Liikunnan lisääntyminen on tutkimuksissa ollut seurausta alhaisemmasta eläintiheydestä ja pitävämmästä lattiamateriaalista, minkä vuoksi eläimet ovat olleet aktiivisempia. Liikunnan seurauksena eläimet kuluttavat enemmän energiaa ja niihin kerääntyy enemmän lihaskudosta ja vähemmän rasvakudosta.

Naudan ruhojen rasvoittumista voidaan jonkin verran säädellä ruokinnalla. Tällöin kysymykseen tulee lähinnä ruokinnan energiapitoisuuden vähentäminen loppukasvatuksessa. Teuraspainojen madaltaminen olisi kuitenkin todennäköisesti tehokkaampi keino rajoittaa ruhojen rasvoittumista kuin energian saannin rajoittaminen tai väkirehun osuuden vähentäminen dieetissä. Nykytilanteessa, jossa kotimaisen naudanlihan tarjonta ei kata kotimaista kysyntää, teuraspainojen madaltamiselle ei kuitenkaan liene perusteita. Liharotuisten nautojen jalostuksellinen valinta residuaalisen syönnin perusteella voisi olla tulevaisuudessa yksi mahdollinen keino tuottaa vähärasvaisempia ruhoja.

Asiasanat: naudanlihantuotanto, ruhon laatu, rasva, ruokinta, rehut, tuotantoympäristöt 


\section{Johdanto}

Suomessa naudanlihantuotanto perustuu pääosin maitorotuiseen eläinainekseen. Kotimaisen naudanlihantuotannon määrä on pystytty säilyttämään kohtuullisesti kotimaista kysyntää vastaavana teuraspainojen nostamisen ja emolehmätuotannon lisäämisen avulla. Maitorotuisten eläinten teuraspainojen nousu on kuitenkin samalla lisännyt jonkin verran ruhojen rasvoittumista. Tämän kirjallisuusselvityksen tarkoituksena oli kartoittaa mahdollisuuksia vaikuttaa naudan ruhojen rasvoittumiseen.

\section{Ruhon rasvaisuuteen vaikuttavat muut kuin ruokinnalliset tekijät Valo}

Valaistuksen on todettu vaikuttavan nautojen lisääntymiseen, liikkuvuuteen, terveydentilaan sekä tuotokseen. Lisävalaistuksen on todettu lisäävän eläinten vuorokauden aikana tapahtuvien syöntijaksojen määrää ja vaikuttavan näin välillisesti tuotokseen. Vanhemmat eläimet eivät ole yhtä herkkiä päivän pituuden vaihtelulle kuin nuoremmat eläimet. Yksityiskohtaisempaa tietoa valon vaikutuksesta eläintuotokseen naudoilla on saatavissa Kauppisen ym. (2004) kirjallisuustutkimuksesta. Phillipsin ym. (1997) tekemässä tutkimuksessa päivää keinotekoisesti pidennettäessä härkien ruhon rasvaisuus väheni verrattuna lyhyen päivän olosuhteissa kasvatettaviin härkiin. Vastaavaa tulosta ei kuitenkaan saatu Zinnin ym. (1989) kokeessa.

\section{Kasvatusympäristö}

Useissa ryhmäkokoa ja eläintiheyttä käsittelevissä tutkimuksissa karsinaan on sijoitettu erilainen eläinmäärä eri eläintiheyksissä, mikä vaikeuttaa tulosten tulkintaa ja vertailua. Näissä tutkimustuloksissa on kuitenkin lähes poikkeuksetta ollut suuntauksena, että ryhmäkoon ja erityisesti eläintiheyden kasvattaminen vaikuttaa negatiivisesti lihanautojen kasvuun (Tuomisto ym. 2004). Ruhon tai lihan laatuun ryhmäkoolla kuten ei myöskään karsinan pohjamateriaalilla näyttäisi olevan vaikutusta.

Ruotsalaisissa tutkimuksissa Mossberg ym. $(1992,1993)$ vertasivat sonnivasikoiden ja sonnien tuotantoa lämpimässä rakennuksessa rakolattiapohjaisissa karsinoissa ja kylmäpihatossa tilavammissa, osittain kuivitetuissa betonipohjaisissa karsinoissa. Karsinatyypillä ei ollut vaikutusta sonnien kasvuun, rehunkulutukseen tai rehuhyötysuhteeseen, mutta kylmäpihatossa sonnien ruhoihin kerääntyi vähemmän rasvaa kuin rakolattialla (Mossberg ym. 1992, 1993). Lisäksi toisessa kokeessa sonnien teurasprosentti oli suurempi kylmäpihatossa kuin rakolattialla (Mossberg ym. 1993). Kylmäpihaton sonnien vähäisemmän rasvoittumisen Mossberg ym. (1992) esittivät olevan seurausta kylmäpihaton alhaisemmasta eläintiheydestä ja pitävämmästä lattiamateriaalista, minkä vuoksi eläimet mahdollisesti olivat aktiivisempia kuin rakolattialla. Liikunnan seurauksena pihaton eläimet kuluttivat enemmän energiaa ja niihin kerääntyi enemmän lihaskudosta ja vähemmän rasvakudosta kuin rakolattialla.

\section{Sukupuoli}

Sukupuoli vaikuttaa ruumiin kudosten kasvuun ja siten myös ruhon koostumukseen ja painon jakautumiseen eri kudoksiin (Jokela \& Rinne 1998). Selvin ero on ruhon rasvoittumisessa. Hiehot rasvoittuvat aikaisemmin kuin härät, jotka puolestaan rasvoittuvat aikaisemmin kuin sonnit (Micol ym. 1991). Samoin rasvoittumisnopeus on suurin hiehoilla, minkä vuoksi sonneilla on laajempi teurasoptimialue kuin hiehoilla. Hiehoilla ruhot ovat rasvaisempia sisäelinten ja rintalastan ympäriltä verrattaessa sonneihin (Murphey ym.1984). Hiehoilla ja sonneilla rasva kerääntyy elimistöön eri vauhtia eri paikkoihin. Hiehoilla rasvan määrä voidaan tarkemmin määritellä ulkoisesta olemuksesta kuin sonneilla. Sonneilla on vähemmän rasvaa ja rasvaa on ohuemmalta kuin härillä, mutta toisaalta marmoroitumista esiintyy enemmän kuin härillä (Eichhorn ym. 1985).

\section{Rotu}

Eri rodut ja risteytykset eroavat toisistaan rasvoittumispisteen (ts. missä painossa eläin alkaa rasvoittua) (Jones ym. 1994) osalta. Aikuispainoltaan suurikokoiset rodut (esim. Charolais, Simmental ja Limousin) kasvavat nopeammin ja rasvoittuvat hitaammin kuin pienikokoiset rodut (Aberdeen angus, Hereford, Shorthorn, Highland cattle) (Jones ym. 1994). Rodut, jotka rasvoittuvat myöhään ja/tai hitaasti, soveltuvat paremmin oloihin, joissa rehua on runsaasti saatavilla ja eläimet voidaan kasvattaa korkeisiin teuraspainoihin. Aikaisin rasvoittuvia rotuja taas voidaan käyttää oloissa, joissa ruokinta on rajoitetumpaa, tai jos eläimet on syytä teurastaa pienemmissä painoissa. Kaikki eläimet eivät menesty samalla ruokinnalla yhtä hyvin. Pienikokoisten, varhain kehittyvien rotujen eläimet ovat paremmin 
sopeutuneet karkearehun hyödyntämiseen, kun taas väkirehuvaltaisella ruokinnalla suuret rodut pääsevät näyttämään kasvutaipumuksensa. Oloissa, joissa rehun laatua ei voida kovin tarkkaan taata, saattaa pienillä roduilla olla etulyöntiasema. Pienet rodut sietävät enemmän vaihtelua, mikä johtuu rasvan kerääntymisestä ruhoon ja antaa enemmän pelivaraa teurastuksen ajankohdalle. Usein pienet rodut myös selviävät paremmin rajoitetulla ruokinnalla.

\section{Teuraspaino}

Teuraspaino kuvaa parhaiten ruhon kokoa, ja siinä esiintyy selviä rotujen ja sukupuolten välisiä eroja (Jokela \& Rinne 1998). Mitä suurempi on eläimen teuraspaino, sitä enemmän ruhossa on punaista lihaa. Hiehojen suuren teuraspainon tavoittelun estää niiden aikainen rasvoittumistaipumus. Teurasprosentti vaihtelee naudoilla 45:n ja 60 prosentin välillä. Teurasprosentti yleensä paranee painon noustessa kuten myös ruokinnan energiatason kasvaessa. Ruhon rasvoittuneisuus niin ikään kohottaa teurasprosenttia. Teurasprosentteihin eniten vaihtelua aiheuttavat pään ja sisärasvojen määrä sekä suolen sisältö.

Saavutettuaan sukukypsyyden, eläimen kasvu muuttuu eli lihaksia nopeammin kasvaa rasvakudoksen määrä Robelin \& Tulloh 1992). Sukupuolen ja rodun sisällä painavammat eläimet ovat yleensä rasvaisempia. Niinpä teuraspaino pitäisi valita siten, että eläin olisi kasvunvaiheessa, jossa rasvaisuus on optimitasolla. Käytännössä on kuitenkin erittäin vaikeaa määrittää tätä pistettä. Teuraspainon kasvu lisää ruhojen rasvaisuutta, ja esimerkiksi Keanen ja Allenin (1998) kokeessa painavammat eläimet olivat rasvaisempia, kuin alhaisemmassa painossa teurastetut. Myös Steen ja Kilpatrick (2000) havaitsivat, että teuraspainon nouseminen lisäsi merkittävästi ruhon rasvaisuutta ja vähensi lihan ja luun osuutta ruhossa.

\section{Kasvunopeus}

Kasvunopeudella tarkoitetaan aikayksikössä saavutettua painonlisäystä. Elopainon kasvunopeudesta käytetään myös nimitystä päiväkasvu. Teuraspainon kasvunopeutta nimitetään taas nettokasvuksi. Kasvunopeuden yksiköksi tulee siten $\mathrm{g} / \mathrm{pv}$ tai kg/pv. Kasvunopeus on tärkeimpiä tekijöitä lihantuotannossa. Hyvään kasvuun liitetään usein suuri lihamäärä, hyvä lihakkuus ja vähäinen rasvanmuodostus. Nopein kasvuvaihe ay-rotuisilla sonneilla on ollut ikävälillä 4-6 kk (Atria Oy:n teurasaineisto).

Lihas- ja rasvakudoksen kasvu perustuu niissä olevien solujen koon suurenemiseen ja/tai lukumäärän lisääntymiseen (Jokela \& Rinne 1998). Kudosten kasvuun ja valkuaisaineenvaihduntaan vaikuttavat lukuiset kasvutekijät ja hormonit. Kasvunopeudella on erityisesti vaikutusta lihan laatuun, sillä nopeasti kasvaneet naudat voidaan teurastaa nuorempina, millä on myönteinen vaikutus lihan syöntilaatuun (Gerhardy 1995). Nopeaan kasvuun liittyy yleensä myös rasvoittuminen: nopeasti kasvaneet eläimet ovat yleensä rasvaisempia kuin hitaasti kasvaneet eläimet (Jurie ym. 1995, Manni 1998, Herva ym. 200X, manuscript submitted). Geayn ja Micolin (1989) mukaan rasvan kertyminen ruhoon lisääntyy päiväkasvun nopeutuessa ja energian saannin lisääntyessä. Rasvoittuminen parantaa yleensä lihan syöntilaatua, vaikka se heikentääkin ruhon laatua (Jokela \& Rinne 1998).

\section{Ruokintastrategian vaikutus ruhoon Ruokintataso ja väkirehu/karkearehu -suhde}

Naudan käyttöön tulevan energian ja/tai ravintoaineiden määrää voidaan säädellä rajoittamalla eläinten kuiva-aineen syöntiä tai antamalla eläimille erilaatuisia rehuja ruokahalun mukaan. Näiden menetelmien vaikutukset ruhoon ovat erilaisia. Esimerkiksi väki- ja karkearehun suhteen muuttaminen voi rehujen laadusta riippuen vaikuttaa huomattavasti eläinten käytettäväksi tulevan energian ja ravintoaineiden määriin (Keane \& Fallon 2001). Ruokintatason noustessa myös ruhon rasvaisuus ja lihakkuus yleensä lisääntyvät. Rasvaisuutta lisäsi Keanen ja Fallonin (2001) tutkimuksessa myös pidentynyt kasvatusaika.

Ruokinnan energiapitoisuuden pienentäminen karkearehun osuutta kasvattamalla vähentää yleensä ruhojen rasvoittumista (esim. Patil, ym. 1993, Schaake ym. 1993). Useissa tutkimuksissa väkirehumäärän suurentaminen ja sen seurauksena eläinten kokonaisenergian saannin lisääntyminen on lisännyt naudan ruhojen rasvoittumista (Aronen ym. 1994, Joki-Tokola ym. 1995, Manni 1998). Mayn ym. (1992) kokeessa havaittiin, että mitä korkeampaa ruokintatasoa kokeessa käytettiin, sen rasvaisempia härkien ruhot olivat. Kokeessa käytettiin hereford $\mathrm{x}$ angus härkiä. Myös suomalaisessa li- 
hanauta-aineistossa voimakas ruokinta on lisännyt risteytyseläinten ruhojen rasvoittumista (Manninen ym. 1994).

Crousen ym. (1985) tutkimuksessa korkeaenergisellä rehustuksella eläimet kasvoivat nopeammin kuin matalaenergisellä rehustuksella. Tässä kokeessa huomattiin kuitenkin, että korkeaenergisellä rehustuksella kasvoi lähinnä ruhon rasvan mutta ei niinkään lihan määrä. Martinsson (1990) havaitsi kokeessaan rasvan määrän lisääntyvän ja luuprosentin pienenevän eläimillä, joiden väkirehutaso oli korkeampi. Mikäli dieetin energiapitoisuus oli suuri, saman painoisten eläinten (riippumatta rehuannoksen suuruudesta) ruhot olivat yhtä rasvaiset (Oltjen ym. 1985). Dieetin energiapitoisuuden ollessa pieni, rajoitetusti ruokitut eläimet olivat saman painoisina vähärasvaisempia kuin vapaasti rehua saaneet (Oltjen ym. 1985). Steen ja Kilpatrick (2000) ovat päätyneet johtopäätökseen, että teuraspainojen madaltaminen on kuitenkin selkeästi tehokkaampi keino rajoittaa ruhojen rasvoittumista kuin energian saannin rajoittaminen tai väkirehun osuuden vähentäminen dieetissä. Tulos pätee tekijöiden mukaan nurmisäilörehuun ja väkirehuun perustuvalla ruokinnalla.

\section{Rehuannoksen valkuaispitoisuus}

Rehuannoksen valkuaispitoisuuden vaikutuksia nautojen kasvuun on tutkittu runsaasti. Mitä paremmin perusruokinnasta saatava energia ja ravintoaineet riittävät tyydyttämään nautojen geneettisesti määräytyvästä kasvutaipumuksesta johtuvan tarpeen, sitä pienempi on lisävalkuaisella saatu kasvun lisä (Huuskonen 2009a). Valkuaislisän vaikutukset ruhon koostumukseen ovat yleensä olleet vähäisiä (McKinnon ym. 1993, Huuskonen ym. 2007, 2008, Huuskonen 2009b). Bergen ym. (1993) tutkimuksessa runsaimmin valkuaista saaneiden härkien ruhot sisälsivät vähemmän rasvaa ja enemmän punaista lihaa kuin muiden ryhmien. Arosen \& Toivosen (1995) kokeessa lisävalkuaista saaneet sonnit taas olivat rasvaisempia kuin ilman valkuaista kasvaneet. Fiemsin ym. (1995) kokeessa valkuaispitoisuudella $(10,3 ; 11,8$ ja 14,2 \% kuiva-aineesta) ei ollut vaikutusta Belgian blue -rodun sonnien kasvuun eikä ruhon laatuun elopainon lisääntyessä 375:stä $718 \mathrm{~kg}$ :aan. Dieetin valkuaispitoisuuden nostaminen korvaamalla ohraa soijalla loppukasvatettavien lihanautojen säilörehupohjaisella ruokinnalla on lisännyt ruhojen rasvaisuutta useissa kokeissa (esim. Steen \& Robson 1995, Steen 1996a). Näiden eri tutkimusten tulosten perusteella voi päätellä, ettei valkuaislisä ehkäise ruhojen rasvoittumista ainakaan kasvavilla sonneilla.

\section{Kompensatorinen kasvu}

Mikäli nautojen kasvu on suhteellisen hidasta kasvatuskauden alussa riittämättömän energian ja/tai ravintoaineiden saannin takia, mutta myöhemmässä vaiheessa ravinnon saanti lisääntyy, havaitaan usein kompensatorista kasvua (Manni 1998). Tällöin rajoitetusti kasvaneet eläimet kasvavat nopeammin kuin alkukasvatusvaiheessa runsaammin rehua saaneet naudat. Rehun muuntosuhde saattaa kompensatorisesti kasvaneilla eläimillä olla parempi, sillä niiden ylläpitoenergian tarve on kasvatuskauden aikaisesta pienemmästä elopainosta ja runsaasti energiaa kuluttavien sisäelinten pienemmästä koosta johtuen pienempi. Toisaalta osa loppukasvatusvaiheen suuremmasta elopainon kasvusta saattaa aiheutua suuremmasta ruuansulatuskanavan kasvusta ja sen sisällön määrästä, jolloin ruhotuotoksessa havaittu hyöty jää vähäisemmäksi kuin elopainon perusteella arvioitu. Kompensatorisen kasvun ilmenemisen voimakkuuteen vaikuttavat tekijät voidaan jakaa kahteen luokkaan. Nämä ovat ravinnon saannin rajoittamisen luonne sekä naudan ikä, koko ja kasvu ravinnon saannin alkamis- tai loppumisajankohtana. Ravinnon saannin rajoittamisen luonteella tarkoitetaan sen kestoa, ankaruutta ja koostumusta rajoittavan ravintoaineen mukaan (Nissi ja Pietola 1999).

Tutkimustulokset kompensatorisen kasvun vaikutuksista ruhon rasvaisuuteen eroavat hieman toisistaan. Mannin (1998) tutkimuksessa kasvun jaksotus vähensi ruhojen rasvaisuutta. Sekä korvaavasti että taantuvasti kasvaneiden sonnien ruhot olivat vähärasvaisempia kuin tasaisesti kasvaneiden. Useissa tutkimuksissa korvaavasti kasvaneet naudat ovatkin olleet vähärasvaisempia verrattuna koko ajan runsaasti ruokittuihin nautoihin (Horton ym. 1992, Henricks ym. 1994). Aikaisemmista tutkimuksista löytyy kuitenkin myös päinvastaisia tuloksia, eli korvaavasti kasvaneet naudat rasvoittuivat tasaisesti kasvaneita enemmän (Abdalla ym. 1988, Rinne ym. 1998). Vaihtelu eri tutkimusten välillä saattaa johtua kasvatusajan pituudesta ruokinnan rajoituksen jälkeen. Ruhojen rasvoittuminen on yleensä korvaavan kasvun alussa vähäistä, mutta lisääntyy sitä mukaa, kun eläimet saavuttavat lopullista kokoaan. 


\section{Rehujen laadun vaikutus Väkirehun laatu}

Tärkkelyspitoinen väkirehu (esim. ohra) fermentoituu pötsissä nopeammin kuin runsaasti kuitua sisältävä väkirehu (tuoreleike, melassileike, ohrarehu) Jokela \& Rinne 1996). Kuitupitoisten väkirehujen sulavuus ja energia-arvo ovat yleensä vähän heikommat kuin tärkkelyspitoisten rehujen. Kuitupitoista väkirehua syötettäessä propionihapon osuus pötsin haihtuvista rasvahapoista kasvaa, ja alkueläinten määrä pötsissä pienenee ohraruokintaan verrattuna. Pötsin käymistyypin vaikutuksia lihantuotantoon ei tunneta kovin hyvin. Propionihappo on märehtijän aineenvaihdunnassa glukogeeninen kuten eräät aminohapot. Jos aminohapoista on pulaa, voi runsaalla propionihapon tuotannolla olla nautojen kasvua parantava vaikutus. Erilaisten energiaväkirehujen käytöllä ei yleensä ole tutkimuksissa ollut vaikutusta ruhojen rasvoittumiseen, jos eläinten energian saanti on ollut samalla tasolla eri ruokintaryhmien välillä (Jokela \& Rinne 1996). Schwarzin ym. (1991) tutkimuksessa maissia väkirehuna saaneet simmental sonnit kasvoivat nopeammin kuin vehnäväkirehua saaneet sonnit. Maissia saaneilla sonneilla myös ruhojen rasvoittuminen oli voimakkaampaa ja sen myötä myös marmoroituminen niiden lihassa oli voimakkaampaa kuin vehnällä ruokituilla sonneilla. Kuitenkin tässäkin kokeessa energian saanti selittänee erot ruokintojen välillä, sillä maissin energia-arvo oli suurempi kuin vehnän.

\section{Karkearehun laatu}

Karkearehun laatu vaihtelee huomattavasti mm. rehulajista (laidun, säilörehu, heinä, olki), kasvilajista ja -lajikkeesta, kasvuolosuhteista (sää, maaperä, lannoitus), kasvien kehitysasteesta, korjuutappioista ja rehun säilönnällisestä laadusta (hygieeninen laatu, säilörehun käymislaatu) johtuen (Jokela \& Rinne 1998). Karkearehun sulavuus vaikuttaa siihen, kuinka paljon eläin pystyy rehua syömään, joten sulavuuden vaikutus nautojen kasvuun on suuri. Karkearehun laatu todennäköisesti vaikuttaa ruhojen rasvoittumiseen lähinnä energian saannin ja kasvunopeuden kautta. Esimerkiksi Suvitien ja Mannisen (1992) tutkimuksessa säilörehua ja rehuviljaa saaneet hiehot kasvoivat nopeammin ja rasvoittuivat enemmän kuin heinää ja rehuviljaa saaneet hiehot. Säilörehua saaneiden hiehojen kokonaiskannattavuus oli kuitenkin Suvitien ja Mannisen (1992) tutkimuksessa hieman parempi, koska niiden kasvatusaika oli lyhyempi ja rehukustannukset pienemmät kuin heinäryhmällä.

Yleensä naudat kasvavat nopeammin syödessään varhaisella kehitysasteella korjattua säilörehua, koska sen sulavuus on parempi kuin myöhemmällä kehitysasteella tehdyn rehun. Yleensä myös parhaiten sulavaa säilörehua syöneet, eniten energiaa saaneet ja siten parhaiten kasvaneet naudat ovat rasvaisimpia (Aronen ym. 1994, Jokela \& Rinne 1998). Nauta syö esikuivattua säilörehua yleensä enemmän kuin tuoreena korjattua, mutta kasvutuloksiin esikuivatun rehun käyttö ei kuitenkaan vaikuta (Flynn 1988). Näin ollen rehun muuntosuhde on huonompi esikuivatulla säilörehulla tuoreeseen säilörehuun verrattuna. Ruhon rasvoittumiseen esikuivatun rehun käyttäminen ei aiheuttane muutoksia (Jokela \& Rinne 1998).

\section{Residuaalinen syönti ja ruhon rasvoittuminen}

Liharotuisten nautojen jalostuksellinen valinta residuaalisen syönnin perusteella voisi olla tulevaisuudessa yksi mahdollinen keino tuottaa vähärasvaisempia ruhoja. Residuaalinen syönti on yksi mahdollinen tapa mitata kasvavan eläimen rehunhyväksikäyttöä (Pesonen 2010). Residuaalinen syönti on erotus, joka muodostuu eläimen todellisesta syönnistä ja arvioidusta syönnistä saavutettua tuotantotulosta kohden. Residuaalinen syönti periytyy keskinkertaisesti. Energian muuntosuhteelta tehokkailla eli alhaisen residuaalisen syönnin eläimillä on tutkimuksissa todettu muodostuvan vähemmän rasvaa kuin korkean residuaalisen syönnin eläimillä (Baker ym. 2006, Lancaster ym. 2009).

\section{Yhteenveto ja johtopäätökset}

Naudan ruhojen rasvoittumista voidaan jonkin verran säädellä ruokinnalla. Tällöin kysymykseen tulee lähinnä ruokinnan energiapitoisuuden vähentämien loppukasvatuksessa. Teuraspainojen madaltaminen olisi kuitenkin todennäköisesti tehokkaampi keino rajoittaa ruhojen rasvoittumista kuin energian saannin rajoittaminen tai väkirehun osuuden vähentäminen dieetissä. Nykytilanteessa, jossa kotimaisen naudanlihan tarjonta ei kata kotimaista kysyntää, teuraspainojen madaltamiselle ei ilmeisesti liene perusteita. Liharotuisten nautojen jalostuksellinen valinta residuaalisen syönnin perusteella voi olla tulevaisuudessa yksi mahdollinen keino tuottaa vähärasvaisempia ruhoja. 


\section{Kirjallisuus}

Abdalla, H.O., Fox, D.G. \& Thonney, M.L. 1988. Compensatory gain by Holstein calves after underfeeding protein. J. Anim. Sci. 66: 2687-2695.

Aronen, I., Lampila, M. \& Hepola, H. 1994. Comparisons of diets based on grass silage, hay or oat straw supplemented with four levels of concentrates in the feeding of growing Ayrshire bulls. Agric. Sci. Finl. 3: 15-26.

Baker, S. D., Szasz, J.I., Klein, T.A., Kuber, P.S., Hunt, C.W.,Glaze Jr., J.B., Falk, D., Richard, R., Miller, J.C., Battaglia, R.A. \& Hill, R.A. 2006. Residual feed intake of purebred Angus steers: Effects on meat quality and palatability. J. Anim. Sci. 84: 938-945.

Berge, P., Culioli, J., Rennere, M., Touraille, C., Micol, D. \& Geay, Y. 1993. Effect of feed protein on carcass composition and meat quality in steers. Meat Sci. 35: 79-92.

Crouse, J.D., Ferrell, C.L. \& Cundiff, L.V. 1985 Effects of sex condition, genotype and diet on bovine growth and carcass characteristics. J. Anim. Sci. 60: 1219-1227.

Eichhorn, J.M., Wakayama, E.J., Blomquist, G.J. \& Bailey, C.M. 1986. Cholesterol Content of Muscle and Adipose Tissue from Crossbred Bulls and Steers. Meat Sci. 16: 71-78.

Fiems, L.O., Bogaerts, D.F., Cottyn, B.G., Decuypere, E. \& Boucque, Ch. V. 1995. Effect of protein level on performance, carcass and meat quality, hormone levels and nitrogen balance of finishing Belgian white-blue double-muscled bulls. J. Anim. Physiology and Anim. Nutr. 73: 213-223.

Flynn, A.V. 1988. Factors affecting the feeding value of silage. Teoksessa: Haresign, W. \& Cole, D.J.A. (Toim.). Recent developments in ruminant nutrition 2. Butterworths, London. s. 265-273.

Geay, Y. \& Micol, D. 1989. Growing and finishing cattle. Teoksessa: Jarrige, R. (Toim.). Ruminant Nutrition. Recommended Allowances \& Feed Tables, s. 121-151. John Libbey and Co Ltd, England.

Gerhardy, H. 1995. Quality of beef from commercial fattening systems in Northern Germany. Meat Sci. 40: $103-120$

Henricks, D.M., Jenkins, T.C., Ward, J.R., Krishnan, C.S. \& Grimes, L. 1994. Endocrine responses and body composition changes during feed restriction and realimentation in young bulls. J. Anim. Sci. 72: 22892297.

Herva, T., Huuskonen, A., Virtala, A.-M. \& Peltoniemi, O. 200X. On-farm welfare and carcass fat score of bulls at slaughter. Manuscript submitted to Livest. Sci.

Horton, G.M.J., Pitman, W.D. \& Pate, F.M. 1992. Protein supplements for corn-silage diets and their effect on subsequent growth and characteristics in beef cattle. J. Anim. Sci. 72: 595-602.

Huuskonen, A. 2009a. Concentrate feeding strategies for growing and finishing dairy bulls offered grass silagebased diets. MTT Science 1: 99 s. Väitöskirja.

Huuskonen, A. 2009b. The effect of cereal type (barley versus oats) and rapeseed meal supplementation on the performance of growing and finishing dairy bulls offered grass silage-based diets. Livest. Sci. 122: 53-62.

Huuskonen, A., Khalili, H. \& Joki-Tokola, E. 2008. Need for protein supplementation in the diet of growing dairy bulls fed total mixed ration based on moderate digestible grass silage and barley. Agric. Food Sci. 17: 109120.

Huuskonen, A., Khalili, H. \& Joki-Tokola, E. 2007. Effects of three different concentrate proportions and rapeseed meal supplement to grass silage on animal performance of dairy-breed bulls with TMR feeding. Livest. Sci. 110: 154-165.

Jokela, M. \& Rinne, M. 1996. Sian ja naudan ruokinnan vaikutus lihan laatuun. Maatalouden tutkimuskeskuksen julkaisuja. Sarja A 7: 99 s.

Joki-Tokola, E., Aronen, I. \& Vehkaoja, H. 1995. Rehunurmen typpilannoituksen ja säilörehun korjuuajankoh-dan sekä väkirehutäydennyksen vaikutukset säilörehun hyväksikäyttöön naudalla. B. Ruukin kenttätutkimus. Jokioinen: Maatalouden tutkimuskeskus, Tiedote 12/95: 59-70.

Jones, S.D.M., Thorlakson, B. \& Robertson, W.M. 1994. The effect of breed type on beef carcass characteristics and Canadian carcass grade. Canadian J. Anim. Sci. 74: 149-151.

Jurie, C., Robelin, J., Picard, P., Renand, G. \& Geay, Y. 1995. Inter-animal variation in the biological characteristics of muscle tissue in male Limousin cattle. Meat Sci. 39: 415-425.

Kauppinen, R., Nylander, C., Pekkanen, S., Huuskonen, A., Tuomisto, L., Martiskainen, P. \& Mononen, J. 2004. Valon vaikutus tuotantoon naudoilla. Teoksessa: Huuskonen, A. (toim.). Ympäristötekijöiden vaikutukset lihanautojen kasvuun ja hyvinvointiin. Maa- ja elintarviketalous 54. Jokioinen: MTT. s. 54-82.

Keane, M.G. \& Allen, P. 1998. Effects of production system intensity on performance, carcass composition and meat quality of beef cattle. Livest. Prod. Sci. 56: 203-214.

Keane, M.G. \& Fallon, R., J. 2001. Effects of feedings level and duration on finishing performance and slaughter traits of Holstein-Friesian young bulls. Ir. J. Agric. Food Res. 40: 145-160.

Lancaster, P.A., Carstens, G.E., Ribeiro, F.R.B., Tedeschi, L.O. \& Crews Jr, D.H. 2009. Characterization of feed efficiency traits and relationships with feeding behavior and ultrasound carcass traits in growing bulls. J. Anim. Sci. 87: 1528-1539. 
Manni, K. 1998. Väkirehuannoksen jaksotuksen vaikutus naudanlihantuotantoon kahdella väkirehutasolla. Pro gradu -työ. Helsingin yliopisto: Kotieläintieteen laitos. $53 \mathrm{~s}$.

Manninen, M., Huhta, H., Virkajärvi, P., Joki-Tokola, E., Suvitie, M., Puntila, M.-L. \& Röpelinen, A. 1994. Risteytyseläinten ruokinta- ja kasvatuskokeet sekä ruhon ja lihan laatu. Teoksessa: Korhonen, T. \& Toivonen, M. (Toim.). Naudanlihantuotannon kehittäminen. Maa- ja metsätalousministeriö, Helsinki. s. 35-72. ISBN 951-47-8945-8.

Martinsson K. 1990. The Effect of Forage Digestability and Concentrate Supplementation on Performance of Finishing Bulls. Swed. J. Agric. Res. 20: 161-167.

May, S.G., Dolezal, H.G., Gill, D.R., Ray, F.K. \& Buchanan, D.S. 1992. Effects of Days Fed, Carcass Grade Traits, and Subcutaneous Fat Removal on Postmortem Muscle Characteristics and Beef Palatability. J. Anim. Sci. 70:444-453.

McKinnon, J.J., Cohen, R.D.H., Jones, S.D.M., Laarveld, B. \& Christensen, D.A. 1993. The effects of dietary energy and crude protein concentration on growth and serum insulin-like growth factor-I levels of cattle that differ in mature body size. Can. J. Anim. Sci. 73: 303-313.

Micol, D., Robelin, J. \& Geay, Y. 1991. Growth and development of tissues and biological characteristics of muscle: Influence of zootechnical factors. Teoksessa: Ender, K. (Toim.). Proceedings of the 42nd Annual Meeting of EAAP Satellite Symposium "Beef carcass and meat quality evaluation". Rostock, Germany. s. 54-68.

Mossberg, I., Lindell, L., Johnsson, S., Törnquist, M. \& Engstrand, U. 1992. Two housing systems for intensively reared bulls slaughtered in two weight ranges. Acta Agric. Scand., Sect. A, Anim. Sci. 42: 167-176.

Mossberg, I., Lindell, L., Johnsson, S. \& Tornquist, M. 1993. Insulated and uninsulated housing systems for growing bulls fed grass silage ad libitum. Acta Agric. Scand., Sect. A, Anim. Sci. 43: 107-115.

Murphey, C.,E, Johnson, D.D., Smith, G.C., Abraham, H.C. \& Cross, H.R. 1984. Carcass Fatness Evaluations: Sex-Related Differences in the Deposition of External Fat - Steer vs. Heifer. Texad Agricultural Experiment Station 4209/4249: 63-65.

Nissi, V. \& Pietola, K. 1999. Väkirehutason ja ruokinnan jaksottamisen taloudellinen merkitys naudanlihantuotannossa. Maatalouden taloudellinen tutkimuslaitos (MTTL), tutkimuksia 237/1999: 7-65 s.

Oltjen, J.W., Bywater, A.C. \& Baldwin, R.L. 1985. Evaluation of a model of beef cattle growth and composition. J. Anim. Sci. 62: 98-108.

Patil, A.R., Goetsch, A.L., Lewis, Jr., P.K. \& Heird, C.E. 1993. Effects of supplementing growing steers with high levels of partially hydrogenated tallow on feed intake, digestibility, live weight gain, and carcass characteristics. J. Anim. Sci. 71: 2284-2292.

Pesonen, M. 2010. Liharotuisten nautojen rehunhyväksikäyttö ja residuaalinen syönti. Teoksessa: Toim. Anneli Hopponen. Maataloustieteen Päivät 2010, 12.-13.1.2010 [: esitelmät ja posterit]. 7 s. www.smts.fi

Phillips, C.J.P., Johnson, P.N. \& Arab, T.M. 1997. The effect of supplementary light during winter on the growth, body composition and behaviour of steers and heifers. Anim. Sci. 65: 173-181.

Rinne, M., Saastamoinen, K. \& Khalili, H. 1998. Lisää vaihtoehtoja teurassonnien kasvatukseen. Koetoiminta ja käytäntö 5: 7.

Robelin, J. \& Tulloh, N.M. 1992. Patterns of growth of cattle. Teoksessa: Jarrige, J. \& Beranger, C. (toim.). Beef cattle production. World Animal Science, C5, s. 111-130.

Schaake, S.L., Skelley, G.C., Halpin, E., Grimes, L.W., Brown, R.B., Cross, D.L. \& Thompson, C.E. 1993. Carcass and meat sensory traits of steers finished on fescue and clover, summer forage, or for different periods in drylot. J. Anim. Sci. 71: 3199-3205.

Steen, R.W.J. 1996a. Effects of protein supplementation of grass silage on the performance and carcass quality of beef cattle. J. Agric. Sci., Camb. 127: 403-412.

Steen, R.W.J., \& Kilpatrick, D.J. 2000. The Effects of the Ratio of Grass Silage to Concentrates in the Diet and Restricted Dry Matter Intake on the Performane and Carcass Composition of Beef Cattle. Livest. Prod. Sci. 62:181-192.

Steen, R.W.J. \& Robson, A.E. 1995. Effects of forage to concentrate ratio in the diet and protein intake on the performance and carcass composition of beef heifers. J. Agric. Sci., Camb. 125: 125-135.

Suvitie, M. \& Manninen, M. 1992. Risteytyshiehot lihantuottajina. Koetoiminta ja käytäntö 49: 19.

Schwarz, F.J., Kirchgessner, M., Augustini, Ch. \& Temisian, V. 1991. Mastleistung, Schlachtkörper- und Fleischqualität von Jungbullen der Rasse Fleckvieh nach unterschiedlicher Weizen- order Körnermaiszulage in der Endmast (Summary: Fattening characteristics, carcass and meat quality after feeding different amounts of wheat or maize to finishing Simmental bulls). Züchtungskunde 63: 317-327.

Tuomisto, L., Huuskonen, A., Mononen, J., Kauppinen, R., Ahola, L. \& Martiskainen, P. 2004. Ryhmäkoon ja eläintiheyden vaikutus kasvavien lihanautojen tuotantoon ja hyvinvointiin. Teoksessa: Huuskonen, A.(toim.). Ympäristötekijöiden vaikutukset lihanautojen kasvuun ja hyvinvointiin. Maa- ja elintarviketalous 54. Jokioinen: MTT. s. 25-53.

Zinn, S.A., Chapin, L.T., Enright, W.J. \& Tucker, H.A. 1989. Failure of photoperiod to alter body growth and carcass composition in beef steers. J. Anim. Sci. 67: 1249-1257. 